\title{
PLANNING CLIL UNITS IN PRIMARY EDUCATION FROM A COGNITIVE PERSPECTIVE
}

\author{
María del Mar Sánchez Pérez, Universidad de Almería \\ E-mail:spm727@ual.es
}
María Sagrario Salaberri Ramiro, Universidad de Almería
E-mail: sagrario@ual.es

\begin{abstract}
The Content and Language Integrated Learning (CLIL) approach has experienced a considerable growth and it is being progressively integrated into curricula all across Europe. It is a dual educational approach in which content and language must be combined. This approach introduces a new cognitive dimension which is missing in other language learning approaches by the addition of a new competence: using the language to learn. This study intends to analyze a lesson planning process of a CLIL Primary School Science lesson at a Spanish state school focusing on the cognitive dimension of the learning process of both Science content and foreign language skills.
\end{abstract} Keywords: CLIL, cognition, lesson planning, Science, Primary Education.

Resumen: El enfoque AICLE (Aprendizaje Integrado de Contenido y Lengua Extranjera) ha experimentado un crecimiento considerable y se está integrando progresivamente en la enseñanza de toda Europa. Se trata de un doble enfoque educativo en el que se combinan el contenido académico y la lengua extranjera. Este modelo introduce una nueva dimensión cognitiva que no se encuentra en otros enfoques de aprendizaje de lenguas extranjeras añadiendo una nueva competencia: el uso de la lengua para aprender. Este estudio tiene como objeto analizar un proceso de planificación de una unidad AICLE de ciencias en primaria de un colegio público español centrado en la dimensión cognitiva del proceso de aprendizaje de los contenidos académicos y lingüísticos.

Palabras clave: AICLE, cognición, planificación de unidades, ciencias, educación primaria.

\section{INTRODUCTION}

The Content and Language Integrated Learning (CLIL) initiative has experienced a considerable growth and it is being integrated into curricula all across Europe at different educational levels. The domain of at least three languages is regarded as one of the basic skills that everyone should acquire in European educational spaces during the course of 
their learning life (Council of Europe 2001). The intended purpose for these new language policies is to promote a multilingual education, consisting of assessing and developing linguistic repertoires of speakers from early learning stages and throughout a lifetime, and an education for multilingualism, which constitutes a condition of maintaining linguistic diversity. This approach involves learning different subjects such as Science, Arts or History, among others, through a different language, which can be very successful in enhancing the learning of languages and other subjects, and developing in the youngsters a positive "can do' attitude towards themselves as language learners (Marsh and Langé 2000). CLIL is a new educational approach in which content and language must be combined. The language is used as a medium to communicate contents, but also as a subject to learn. CLIL is defined as a dual-focused educational approach in which an additional language is used for the learning and teaching of both content and language with the objective of promoting both content mastery and language to pre-defined levels (Maljers et al. 2010). This approach has gained a tremendous success and its influence on practice is currently expanding quickly across Spain, Europe and beyond (Lasagabaster and Ruiz de Zarobe 2010).

Although teaching content through a foreign language is not a new phenomenon and dates back some thousands years (Mehisto et al. 2008; Tejada Molina et al. 2005), the term was coined in 1994 at the University of Jyväskyla (Finland) and the European Platform for Dutch education (Fortanet-Gómez and Ruiz-Garrido 2009; Marsh 2006). Since the late 1990s, its usage has expanded considerably through Europe and beyond (Marsh 2002). From that decade, many European educational centres have implemented CLIL not only as an innovative approach to the teaching of foreign languages but as a way to achieve the aims stated by the European Commission regarding multilingualism in Europe (Pérez Cañado 2011). The positive effects of CLIL demonstrated by recent research are highly notorious (Cenoz 2009; Dalton-Puffer and Smit 2007; Escobar and Nussbaum 2011; Lasagabaster and Ruiz de Zarobe 2010; Lorenzo et al. 2011, Martínez Agudo 2010; among others). CLIL offers students of all ages a natural context for language development. This naturalness seems to be one of the key factors for successful both of the subject contents and language learning (Navés et al. 2002; Suárez 2005). According to Barbero et al. (2009), CLIL promotes learning through activities that have the features of tasks: involving a primary focus on pragmatic meaning motivates the learners to use the language to communicate contents, and includes cognitive processes such as selecting, classifying, ordering, reasoning and evaluating information. On the other hand, CLIL enhances the second language acquisition more effectively, where acquisition is a kind of subconscious process similar to the way children develop ability in their first language (Krashen 1995). Furthermore, there is evidence that students who learn different languages develop better cognitive processes (Abutalebi et al. 2001; Hahne and Friederici 2001; Hakuta et al. 2010; Lee 2002). These studies show that learning a second language stimulates students' brain and produces beneficial brain activation patterns optimizing psychological development. Content learning is thus beneficial if conducted in a foreign language. This is because, on the one hand, students have to strive to decode the information conveyed in the foreign language and, on the other hand, the teacher must make an extra effort so that all students can reach the information and content in a language different from the native. Moreover, A CLIL approach offers a valid alternative to a model of teaching and learning founded on transmission of knowledge; it aims to build knowledge as construction instead 
of instruction (Marsh 2005), it develops new thinking skills and consequently enhances language acquisition. New information is connected to students' background and experience, and strategies are used to scaffold the students' acquisition of knowledge and skills towards a progressive autonomy (Barbero et al. 2009). CLIL potentialities have been summarized as four essential principles: content, communication, cognition, and culture (Coyle 2002). Their combination makes CLIL a very powerful tool to learn languages and subjects, proposed by European authorities as one of the best strategies to encourage languages learning. Within this perspective, the development of the cognitive dimension in language learning is a real challenge of CLIL (Cummins 2000).

The spinning process of bilingual programmes implementation has caught teachers unaware in the adoption of methodologies adapted to the needs required by the bilingual education projects. Consequently, a desperate demand of new methodological and teaching techniques has arisen among the bilingual teaching community (Salaberri and Sánchez-Pérez 2012). The lack of appropriate teaching materials and lesson planning guidelines in CLIL education has required research on strategies to be implemented in multilingual classrooms. This study intends to analyze a lesson planning procedure of a CLIL Primary School Science lesson focusing on the cognitive dimension of the learning process of both Science content and foreign language skills. For this purpose, the theoretical 4-Cs framework planning tool (Coyle, Hood and Marsh 2010) will be used.

\section{PLURILINGUALISM PROMOTION PLAN IN ANDALUSIA}

The Autonomous Community of Andalusia implemented in 2005 a Plurilingualism Promotion Plan with the attempt to develop "a language policy for Andalusian society" (Junta de Andalucía 2004: 1). This implementation resulted in a network of 400 bilingual Primary and Secondary schools created over the four-year period, the hiring of some 600 native teaching assistants whose task was to monitor and enhance teachers' language competences. Over 50,000 teachers took in-service training in bilingual education and 30,000 students took part in European mobility programmes over three years (Lorenzo 2010, Salaberri 2010). Bilingual sections proved to be a successful move in education, one that brought a new spirit to state education and rendered the whole system a dynamic one able to move with the new winds of multilingual Europe (Lorenzo 2010). In 2011, more than 689 schools in the whole Community had already implemented a bilingual programme including different languages such as English, French or German.

\section{A NEW METHODOLOGICAL APPROACH}

The Content and Language Integrated Learning (CLIL) approach requires a swift in methodologies used in traditional language and content teaching. However, there is still a lack of appropriate teaching materials, strategies and methodological resources. Consequently, a desperate necessity of new methodological and teaching techniques has arisen among the bilingual teaching community (Salaberri and Sánchez-Pérez 2012). It thus becomes highly necessary to foster a well-defined training plan for CLIL teachers (Salaberri 2010). In order to achieve successful CLIL results in primary school classrooms, 
new methodological approaches and strategies are needed (Junta de Andalucía 2004). or this purpose, teachers should encourage among their students activities to develop children's motor, emotional, social and intellectual capacities; oral skills in order to promote interaction; the importance of routine language; a concept-centered vs. grammar-centered approach and avoid fragmented and disperse treatment of content issues. In order to implement learning instructions that meet these principles, there are no standards solutions, but multiple options that allow the creation of multilingual learning techniques. The success of this multilingual global project depends on the design of new curricular organizations and new organizational forms of teaching. Its progressive implementation requires the collective cooperation of the administrative field, in the syllabus and curricula determination and in the teaching practices.

\subsection{Need for an Integrated Curriculum}

Some difficulties in combining the dual perspective language-content in bilingual classrooms have been detected among bilingual teachers. The multilingual school programmes demand a restructuration of the traditional curriculum models. The European Commission has noted the need to adapt language curricula to the Common European Framework of Reference for Language (CEFR) (Council of Europe 2001). This adaptation implies a big change in the in the teaching process of bilingual professionals. The new curricular model must cover all of the languages that are studied at all educational stages (Lorenzo et al. 2005). School communities should be provided with an integrated language and non-language curriculum. Thus language must be integrated into the curriculum and it should be considered as the subject of all subjects and a special framework must be created for language teaching and learning (Junta de Andalucía 2004). It should be reminded that language is a tool which favours and makes possible the structure of knowledge, and at the same time, "it aids in the discovery of another culture, another worldview and other ways of life" (Junta de Andalucía 2004: 33). The language integrated curriculum intends to analyze the possibility of language training defragment. It must lead to language teachers to reflect and consider ways to:

- Allow a better command of written and spoken codes.

- Promote a reflection about communication, human language and foreign languages.

- $\quad$ Encourage a reflexive critic on the knowledge related to languages.

- Publicize the languages heritage in Europe.

- Develop verbal and non-verbal creativity.

- $\quad$ Enter an aesthetic of verbal creations and an approximation to literary texts.

- Know other societies.

This new curricular approach should focus on the student, who should be awarded the category of the person responsible for the learning process, an individual who communicates and develops his or her own learning strategies, and therefore learns to learn. Oral and written skills in the mother tongue and in the foreign language(s) should be taught and practiced in an integrated manner, attempting to simulate real-life communication processes. The development of communicative strategies which compensate the lack of competence 
in the foreign language should be encouraged, as well as the transfer of those which have already been developed in the mother tongue. Oral communication in the classroom is seen as something common to everyone, as well as being the most authentic means of communication. For that very reason, foreign languages should be used as the essential medium of communication. With foreign languages, the classroom context should also be used to create simulations of situations related to the world outside (Junta de Andalucía 2004).

\subsection{Aspects to Take into Account when Tlanning CLIL Units}

In Coyle, Marsh and Hood (2010), several principles in which CLIL teaching should be based on, are presented. Some of those principles are:

- $\quad$ Constructing knowledge should exclude teacher-centered approaches and learning based on memorizing data.

- $\quad$ Language should be developed in social interactions.

- Teaching should be learner-centered.

- Students should have an active role in classroom activities.

- Co-operative learning would be advisable.

- Activities aimed at promoting learner's autonomy should be introduced.

- Co-operation of foreign language teachers with subject teachers would be recommended.

- Task-based and process approach should be carried out.

- The use of variety of teaching techniques with diversity of materials, including computer assisted learning should be planned.

- $\quad$ Learning should always be context-based, placed in natural contexts.

- Different language skills (reading, listening, speaking, writing) should be promoted, not restricted to grammar and vocabulary

- It would be necessary to find a well-balanced approach to teaching content and language.

- $\quad$ Language redundancy (repetition of content with the use of various language means and materials) would be necessary.

All these principles should be taken into account in order to correctly apply CLIL methodology to plurilingual lessons. This means that teachers should develop different kind of activities and materials in order to promote the proper acquisition of both content and language.

\section{NEW COGNITIVE DEMANDS IN CLIL LESSON PLANNING}

Unlike different SLA approaches, CLIL introduces a cognitive dimension through the addition of a new competence: using the language to learn (Barbero et al. 2009). It engages students in higher-order thinking skills in order to foster the communicative competence. Cummins (2000) differentiated between two different types of communication that would be advisable to be taken into account when planning CLIL lessons, related to the social and academic language acquisition. One is the Basic Interpersonal Communication Skills (BICS) 
referring to the language skills needed to operate in social situations, to interact socially with other people. Social interactions are usually context embedded. They occur in a meaningful social context and they are not very demanding cognitively. The other one, Cognitive Academic Language Proficiency (CALP) refers to formal academic learning. This includes listening, speaking, reading, and writing about subject area content, which is essential for students to succeed in their CLIL lessons. CALP does not mean the understanding of content area vocabulary, but includes skills such as comparing, classifying, synthesizing, evaluating, and inferring. Academic language tasks are context reduced. The language also becomes more cognitively demanding: new ideas, concepts and language are presented to the students at the same time. Cummins also advances the theory that there is a common underlying proficiency (CUP) between two languages. Skills, ideas and concepts students learn in their first language will be transferred to the second language. Cummins's quadrant represents the double dimension of CLIL (Figure 1). On the vertical line the cognitive demand, that precedes from the lowest to the highest and on the horizontal line the language that may be more or less embedded in a context. The context is considered an important element to highlight the meaning: experiences in bilingual studies show that children are able to manifest much higher levels of cognitive performance when the task is embedded in a concrete context (Baker 2002).

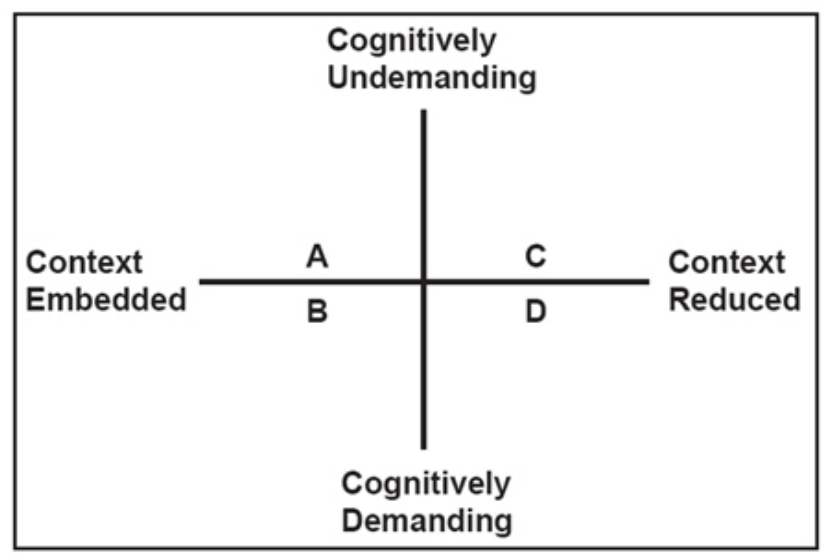

Figure 1. Range of contextual support and degree of cognitive involvement in language tasks and activities (Cummins 2001)

Lesson planning proceedings should take into account all these different elements: language level, cognitive demands and context, since "language and content will be acquired most successfully when students are challenged cognitively but provided with the contextual and linguistic supports" (Cummins 2000: 71). In CLIL lessons, new information must be integrated with what the learner already knows in order to subsequently demand higher order thinking skills. So it is important for teachers to make explicit connections between new learning and the material, vocabulary and concepts previously covered in class through the design of specific tasks and materials (Echevarría et al. 2004). 


\section{LESSON PLANNING TOOLS}

\subsection{The 4 Cs Framework}

The present chapter will be focuses on a lesson planning tool offered by Do Coyle (2006): the 4Cs-Framework, which offers a sound theoretical and methodological foundation for planning CLIL lessons and constructing materials because of its integrative nature. The 4Cs-Framework is built on the following principles:

A. Content: Content matter is not only about acquiring knowledge and skills; it is about the learners creating their own knowledge and understanding and developing skills (personalized learning). It is content which initially guides the overall planning along the learning route. At the heart of the learning process lie successful content or thematic learning and the related acquisition of new knowledge, skills and understanding. Content is the subject or the CLIL theme.

B. Cognition: Content is related to learning and thinking. To enable the learners to create their own interpretation of content, it must be analyzed for its linguistic demands; thinking processes need to be analyzed in terms of their linguistic demands. For CLIL to be effective, it must challenge learners to create new knowledge and develop new skills through reflection and engagement in higherorder as well as lower-order thinking. CLIL is not about the transfer of knowledge from an expert to a novice. CLIL is about allowing individuals to construct their own understandings and be challenged.

C. Communication: Language needs to be learned, which is related to the learning context, learning through that language, reconstructing the content and its related cognitive processes. This language needs to be transparent and accessible; interaction in the learning context is fundamental to learning. This has implications when the learning context operates through the medium of a foreign language; Language is a conduit for communication and for learning which can be described as: learning to use language and using language to learn (Coyle 2005). Communication in this sense goes beyond the grammar system. For this purpose, Coyle, Hood and Marsh (2010) defined a language triptych including three different types of language to be taken into account when planning CLIL lessons: i) Language of learning, related to the essential lexicon/grammar associated directly to the topic; ii) Language for learning, referring to the language needed to operate in the lesson that is in real contexts for the learners; and iii) Language through learning: regarding the language needed to engage learners cognitively and to generate new language use.

D. Culture: Studying through a different language is fundamental to fostering international understanding. If learners understand the concept of 'otherness' then this is likely to lead to a deeper understanding of self (Byram 2008). This aspect includes intercultural elements in project planning: setting the context of the content in different cultures. 


\subsection{The CLIL Pyramid}

According to the above mentioned principles, Meyer (2010) designed a CLIL Pyramid to visually represent the idea that quality CLIL based on the principles of the 4Cs-Framework can only be achieved when all of the four Cs are considered in lesson planning and materials construction.

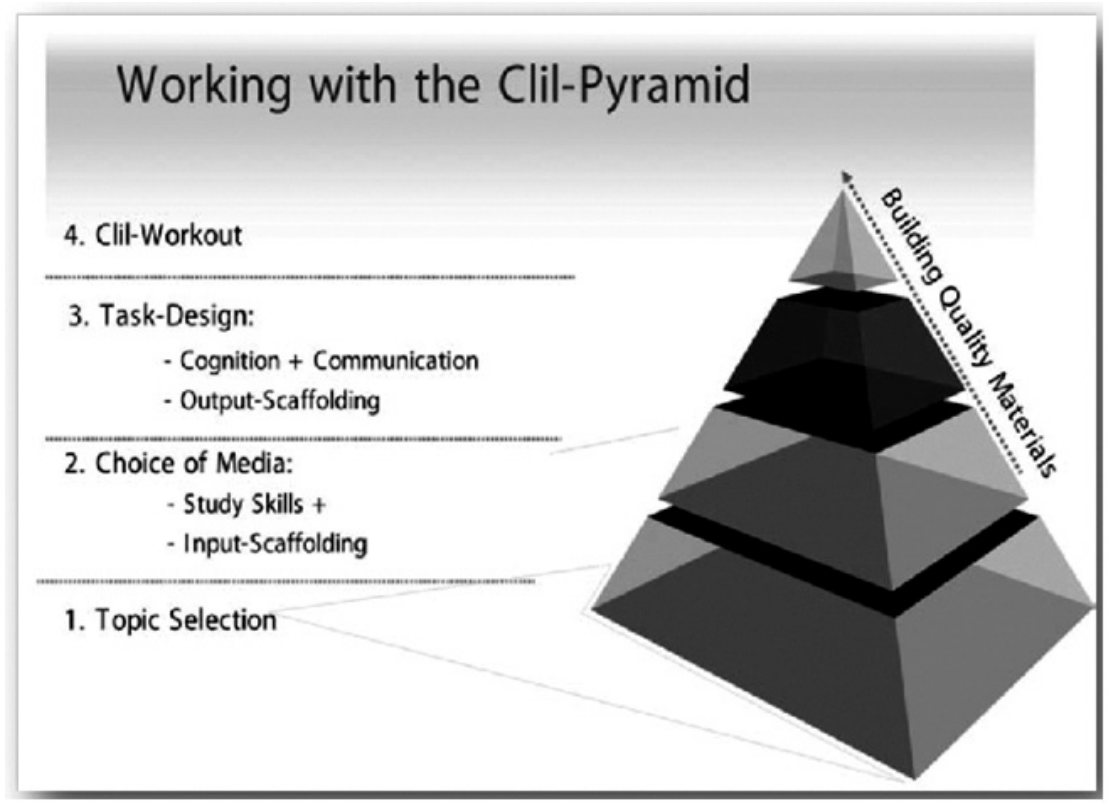

Figure 2. The CLIL Pyramid (Oliver Meyer 2010)

The CLIL-Pyramid suggests a systematical sequence for planning CLIL units and materials, starting with topic selection and ending with a review of key content and language elements that we have come to call the CLIL workout. The stages composing the CLIL Pyramid can be described as follows:

1. Planning a CLIL unit starts with content selection. The specific needs of the content subject are at the heart of every CLIL lesson and the starting point for material construction.

2. Providing multimodal input and distributing it evenly across the new CLIL unit produces highly differentiated materials which accommodate different learning styles and activate various language skills. Such multimodal input can facilitate the development of new literacies.

3. The nature of the selected input (i.e. texts, charts, maps, videoclips, etc.) determines how much and what kind of input-scaffolding is needed. It also indicates which 
subject specific study skills need to be practiced with the students so they can successfully cope with that input.

4. Tasks need to be designed to trigger both higher order thinking skills and lead to authentic communication/interaction in different interactive formats (solo work, pair work, group work, etc.).

5. The nature of the desired output (poster, interview, presentation, map, etc.) determines how much and what kind of output-scaffolding is necessary.

This model seems to have a series of advantages that can be summarized as follows (Fandiño 2011): it enables multifocal lesson planning, that is, the 4 Cs are inextricably linked; higher order thinking skills become an integral part of CLIL lessons; scaffolding, study skills and learning strategies are essential parts of the planning and teaching process; it arises awareness for multi-modal input and accommodates individual learning styles, multiple intelligences and leads to highly differentiated lessons and materials; it is very flexible regarding various models of interaction/cooperation (individual/pair/group work); the intercultural communication is taken seriously.

\section{OBJECTIVES}

The aim of this paper is to present a lesson planning procedure in a CLIL Science Primary School classroom following the CLIL planning theoretical framework of the $4 \mathrm{Cs}$ (Coyle 2005, 2006), as well as a series of activities proposed to achieve a proper acquisition of content and language integrated learning in a bilingual educational setting.

\section{SAMPLE AND METHODOLOGY}

\subsection{Context of the Study}

The teaching sequence under study belongs to a Primary School Science lesson of a state school of the region of Andalusia, a Spanish monolingual community. In order to analyze the lesson planning procedure, a series of meetings with the teacher were planned for material analysis. The session corresponds to the first year of the third cycle of Primary Education ( $5^{\text {th }}$ Primary) and to the non-linguistic area "Science", and the lesson selected for CLIL planning was Unit 8: The Landscape. Students have an exposure to the English content classroom of 3 hours per week. It is worth mentioning that the teacher plays the role of Science teacher and foreign language teacher, which definitely facilitates the purpose of teaching both content and language at the same time.

\subsection{Unit Planning Process}

Before planning the unit, a series of aims and outcomes were defined in accordance with the theoretical framework used under this study (the 4-Cs framework) Coyle (2005, 2006). Table 1 shows these predefined teaching objectives and outcomes. 


\begin{tabular}{|c|c|c|}
\hline Teaching Objectives & Learning Outcomes & COMMUNICATION \\
\hline CONTENT & CONTENT & $\begin{array}{l}\text { LANGUAGE OF } \\
\text { LEARNING }\end{array}$ \\
\hline $\begin{array}{l}\text { Explain the different } \\
\text { landscape forms. }\end{array}$ & $\begin{array}{l}\text { Memoryse key } \\
\text { vocabulary. }\end{array}$ & Content lexicon: \\
\hline $\begin{array}{l}\text { Explain the location of } \\
\text { the different landscape } \\
\text { form in the Spanish map. }\end{array}$ & $\begin{array}{l}\text { Learn the different } \\
\text { landscape form and their } \\
\text { location in the Spanish } \\
\text { map. }\end{array}$ & $\begin{array}{l}\text { (e.g.) What is a mountain? } \\
\text { A mountain is... }\end{array}$ \\
\hline $\begin{array}{l}\text { COGNITION } \\
\text { Make the students think } \\
\text { about the differences } \\
\text { between elements of } \\
\text { landscape. } \\
\text { Ability to locate them on } \\
\text { the Spanish map. }\end{array}$ & $\begin{array}{l}\text { COGNITION } \\
\text { Understand the } \\
\text { differences between the } \\
\text { elements of the Spanish } \\
\text { relief. }\end{array}$ & $\begin{array}{l}\text { LANGUAGE FOR } \\
\text { LEARNING } \\
\text { Language to operate in the } \\
\text { lesson: } \\
\text { (e.g.) Where is ... located? } \\
\text { What is the difference } \\
\text { between...? } \\
\text { LANGUAGE THROUGH } \\
\text { LEARNING } \\
\text { Dictionary use for } \\
\text { vocabulary extension. } \\
\text { Language for feedback. }\end{array}$ \\
\hline
\end{tabular}

Table 1. Unit teaching objectives and outcomes (Adapted from Puntí 2009)

After defining the general objectives and outcomes of the unit, a series of steps were defined to plan the lesson. These were:

i. Step 1: Fixing the content.

ii. Step 2: Connecting content and cognition.

iii. Step 3: Defining language learning.

iv. Step 4: Preparing the materials. 


\section{Step 1: Fixing the Content}

Before designing the activities it was necessary to fix the content or thematic learning as well as to set the related acquisition of new knowledge, skills and understanding. The content should initially guide the overall planning along the learning process in order not to limit it by the linguistic level of the learners. Therefore the teacher should select the most appropriate content taking also into account the CLIL methodology and should select the new knowledge, skills and understanding of the unit. These selections should consider a progression in learning for students.

\section{Example}

Concepts to be learned:

1. Types of Landscape elements.

2. Spanish geography.

3. Spanish rivers and location.

4. Spanish coasts and location.

5. Spanish mountains and location.

6. Spanish plains and location.

Figure 3. Example of content selection in Unit 8

\section{Step 2: Connecting Content and Cognition}

Given an outline of the content, the next step was to analyze and select the thinking skills, problem solving and creativity which connect with the content. Exploring how cognitive elements interconnect with content would determine the type of tasks that will be planned.

\section{Example}

Skills students have to acquire:

1. Understand the differences between landscape elements.

2. Memoryze the different landscape elements of the Spanish relief.

3. Identify landscape elements in other European countries.

4. Learn the location of the different landscape elements on the Spanish map.

5. Know the differences and similarities of lanscape elements in different countries.

6. Assessing the work in groups.

Figure 4. Example of content and cognition connection in Unit 8

\section{Step 3: Defining Language Learning}

The next step links the content and cognitive demands with communication using language learning. Identifying the language needed to learn in a CLIL classroom demands systematic analysis at the planning stage. It requires an analysis of the type of discourse 
and language which is embedded in different content subjects or themes. This relationship implies that the lecturer had to have careful consideration of classroom activities in order to ensure that learners not only have access to the content language, but also to the classroom language needed to carry out the tasks. There may be cases where specific grammar is needed and teachers will make decisions on whether teach this grammar or to propose any other activity to focus the student attention on the use of the new grammar. Therefore, the CLIL lesson would enable the learners to use the new grammar appropriately and follow the discourse norms of the course in accordance with the three types of language defined by Coyle, Hood and Marsh (2010): language of learning, language for learning and language through learning.

\section{Example}

1. Language of learning:

- Key vocabulary

- Grammatical progression (Present simple)

2. Language for learning:

- Defining concepts.

- In groups: asking and explaining.

- Language for locating and describing.

3. Language through learning:

- Using feedback

- Dictionary search skills

- Questioning and answering.

Figure 5. Language learning definition in Unit 8 .

\section{Step 4: Developing Intercultural Awareness}

At the fourth stage, it should be added to the information developed in the previous steps a cultural awareness, that is know how the different elements studied appear in foreign countries (e.g. Europe).

\section{Example}

Intercultural awareness of students:

1. Introduction to basic European geography

2. Examples of landscape elements in the European map.

3. Diversity of European landscapes.

4. Differences between Spanish and European landscape elements.

5. Comparison between Spanish and European geography.

Figure 6. Cultural awareness definition in Unit 8 


\section{RESULTS}

\subsection{Tasks Design}

In order to achieve the outcomes established in the above mentioned CLIL planning steps, the teacher defined a series of tasks to be developed throughout the unit. A series of different task were defined: (1) pre-tasks, aimed at allowing student to get familiar with the main contents of the unit, (2) a main task which would allow students to show their understanding of the contents, and (3) a series of post-task that would serve to reinforce the knowledge acquired within the unit.

For pre-tasks, the teacher engaged the students in the creation of word clouds related to the contents of the unit through a brainstorming session. This activity allowed students to use their previous knowledge on the matter and to get familiar with the lexicon and grammar features in the second language. A series of flashcards were also created to facilitate the acquisition of new vocabulary through this type of multimodal resource and material for reading to reinforce the reading comprehension of the students was prepared.
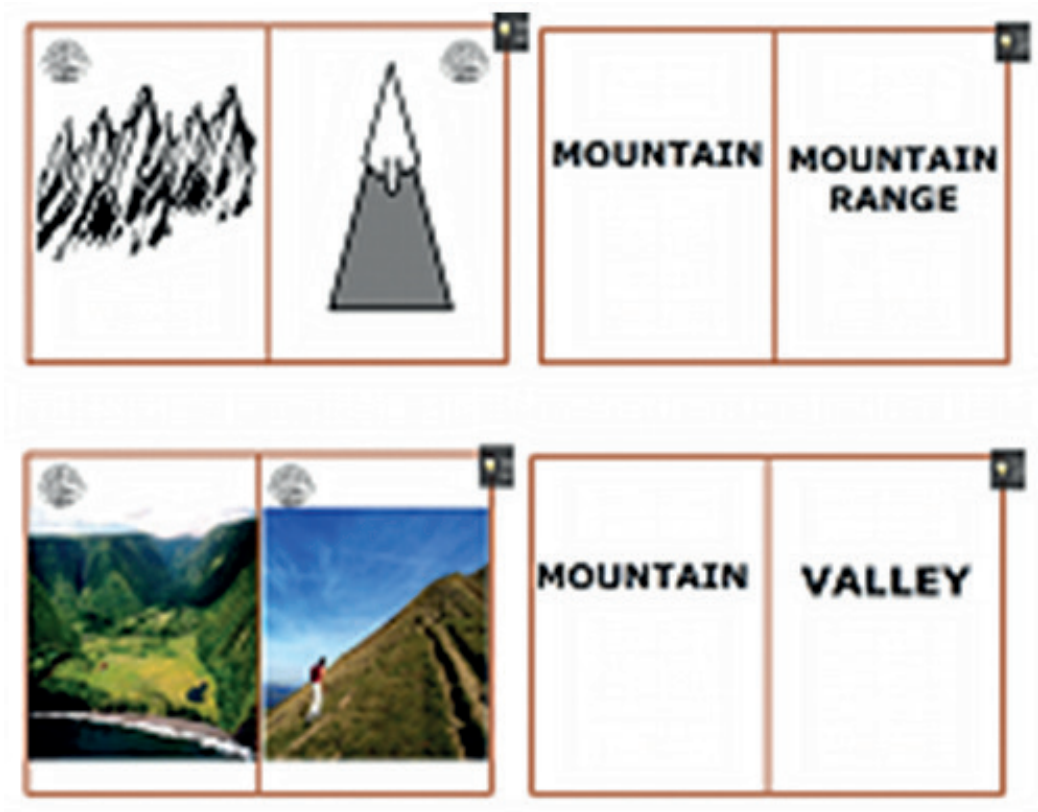

Figure 7. Pre-tasks samples

As for the main task, the teacher asked the students to develop a work in groups, by which they had to complete an empty Spanish relief map in accordance with different aspects. Three different groups were created. Group 1 was asked to complete the map with 
the series of mountains and mountain ranges previously studied, Group 2 with the rivers, and Group 3 with the coasts, oceans and seas. After their completion they had to show their completed map to the rest of the class and elaborate a global map with all the elements included.

\section{Work in groups:}

Group 1 must fulfil the map with the relief

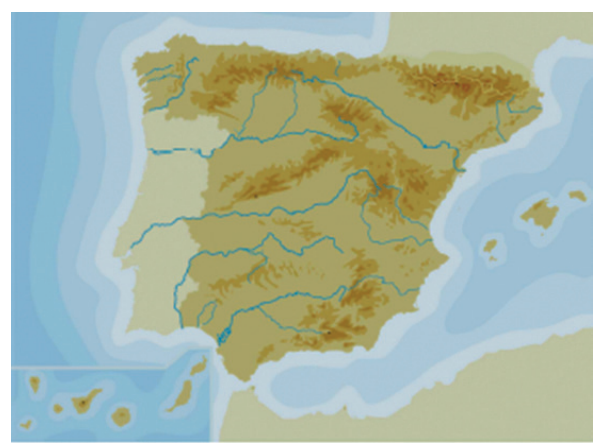
elements.

Group 2 must fulfil the map with the rivers.

Group 3 must fulfil the map with the coasts, oceans and seas.

Map filling and share with the rest of the class. At the end: global map with all the elements.

Figure 7a. Main task description.
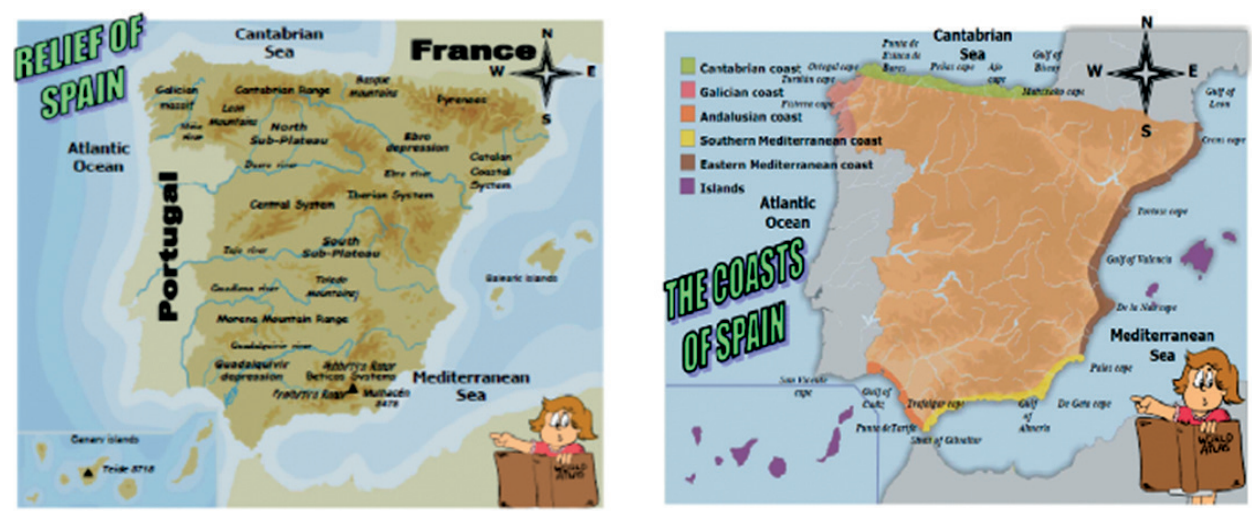

Figure 7b. Main task completion

Once finished the completion of the main task, the teacher asked the students to complete as series of post-task to reinforce their knowledge acquired within the unit. These consisted in the creation of a mind map and a glossary of the new terms learnt during the completion of the previous tasks 
THE LANDSCAPE

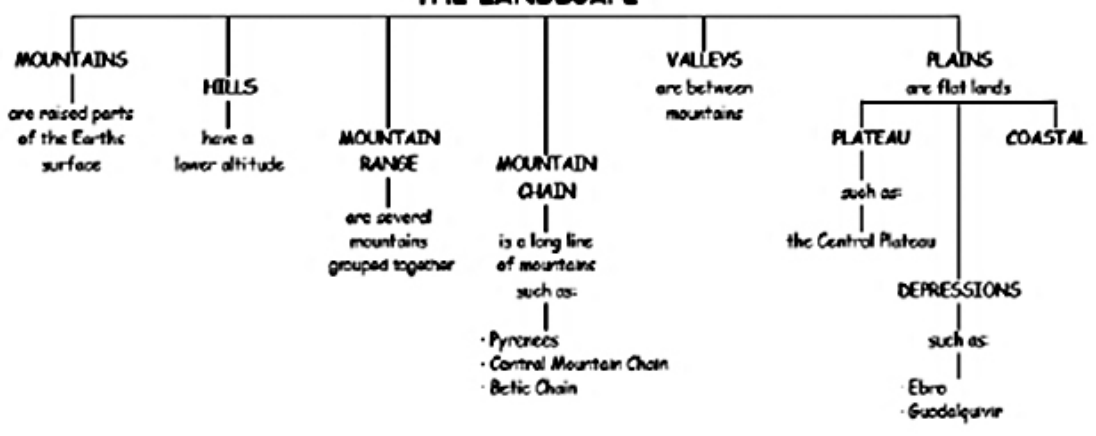

THE COAST

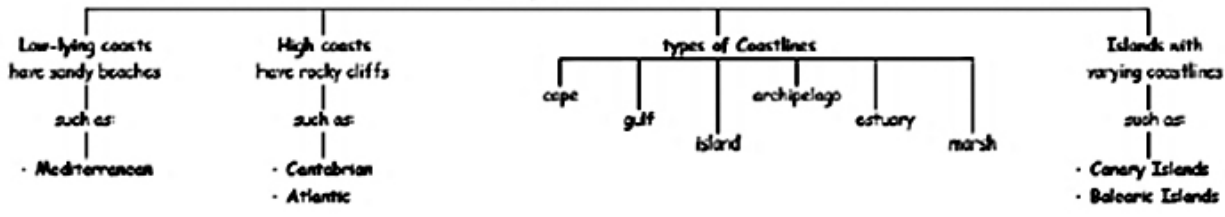

Figure 8. Post-tasks samples

The development of these activities encouraged among the students involved the achievement of different skills such as content-knowledge acquisition as well as language skills development, positive interdependence, personal responsibility, social skills at work and reflection on the work in groups.

\section{CONCLUSIONS}

In this paper a lesson planning procedure used in a CLIL Primary School setting has been shown. It has been tried to offer a different methodological approach to give answer to some of the main questions arising in current bilingual classrooms. A tried and tested planning tool for unit planning for content and language integrated learning has been used as a reference as well as a series of strategies aimed at achieving the necessary objectives for successful bilingual teaching.

The development of this unit plan procedure allowed the teacher to anticipate to the demands of the students in the necessary tools to develop the tasks assigned for a proper acquisition of content knowledge and language skills. The results obtained were very positive and the tasks developed facilitated students a proper content-knowledge acquisition as well as foreign language skills development. It also promoted a positive interdependence and personal responsibility, allowed students to get social skills at work through the interaction.

This paper may provide CLIL teachers with some tips that facilitate their work and that can be reinforced by further contributions so that a major methodological plan that meets the needs of the increasing number of bilingual learners can be established. 


\section{ACKNOWLEDGEMENTS}

This work has been conducted within the framework of the project WAcademic discourse in a foreign language: learning and assessment of science content in the multilingual CLIL classroom", funded by the MICINN (R+D+i EDU2010-15783 project), headed by the Autonomous University of Barcelona (Spain).

\section{REFERENCES}

Abutalebi, J., Cappa, S. F. \& Perani, D. 2001. "The bilingual brain as revelated by funcional neuroimaging”. Bilingualism: Language and Cognition, 4: 179-190.

BAKER C. ED. 2002. Foundations of Bilingual Education and Bilingualism. Multilingual Matters: Clevedon, 3rd edition.

Barbero, T., Damascelli, A., \& Vittoz, M. 2009. "Integrating the Common European Framework of Reference (CEFR) with CLIL". CLIL Practice: Perspectives from the field. Ed. D. Marsh. Jyväskylä: University of Jyväskylä. 102-109.

Byram, M. 2008. From Foreign Language Education to Education for Intercultural Citizenship. Essays and Reflections. Clevedon: Multilingual Matters.

Cenoz, J. 2009 Towards Multilingual Education. Basque Educational Research from an International Perspective. Clevedon: Multilingual Matters.

CouncIL OF Europe 2001. Common European Framework of Reference for Languages: Learning, Teaching, Assessment. Cambridge: Cambridge University Press.

Coyle, D. 2002. "Relevance of CLIL to the European Commission's Language Learning Objectives in CLIL/EMILE". The European Dimension, Public Services Contract $D G E A C: 27-28$

CoYle, D. 2005. "The Teaching Observatory: exploring zones of interactivity in Holmberg”. Languages and Distance Education: Evolution and Change. Eds. G. Holmberg, M. Shelley and C. White, C. Clevedon: Multilingual Matters. 309-326

CoYle, D. 2006. “Towards Strategic Classrooms: learning communities which nurture the development of learner strategies". Language Learning Journal 31, 1: 65-79.

Coyle, D., Hood, P. AND Marsh, D. 2010. Content and Language Integrated Learning. Cambridge: Cambridge University Press.

Cummins, J. 2000. Language, Power and Pedagogy, Multilingual Matters LTD, Clevedon, England.

Cummins, J. 2001. Negotiating identities: Education for Empowerment in a Diverse Society. (2nd ed.). Los Angeles: California Association for Bilingual Education.

Dalton-Puffer, C. And Smit, U. eds. 2007. Empirical Perspectives on CLIL Classroom Discourse. Franktfurt, Vienna: Peter Lang. 
ECHEVARRIA J., Vogt, M. \& SHORT, D. 2004. Making content comprehensible for learners. USA: Pearson.

Escobar Urmeneta, C. \& Nussbaum, L. Eds. 2011. Aprendre en una altra llengua / Learning through another language / Aprender en otra lengua. Bellaterra. Servei de publicacions de la UAB.

FANDIÑO, Y. 2011 "Reflective teaching in EFL teacher education programs". Colombia ASOCOPI Newsletter. Asocopi (Asociacion Colombiana De Profesores De Inglés), 9: $13-20$.

Fortanet-Gómez, I. \& Ruiz-Garrido, M. F. 2009. "Sharing CLIL in Europe”. Content and language integrated learning: Cultural diversity. Ed. M. L. Carrió-Pastor. Frankfurt am Main: Peter Lang. 47-75.

Hahne, A. \& Friederici, A. D. 2001. "Processing a second language: late learnes' comprehesion mechanisms as revealed by event-related brain potentials". Bilingualism: Language and Cognition 4: 123-141.

Hakuta, K., Bialiystok, E. \& Wiley, E. 2003. "Critical evidence: a test of the critical period hypothesis for second-language acquisition”. Psychological Science 14: 31-38.

Junta de Andalucía (2004). Plurilingualism Promotion Plan. Sevilla: Consejería de Educación. 30 Jun. 2014. http://www.juntadeandalucia.es/averroes/plurilinguismo/ planing.pdf

Krashen, S. D. 1995. Principles and practice in second language acquisition. New York: Phoenix ELT.

Lasagabaster, D. \& Ruiz de Zarobe, Y. Eds. 2010. CLIL in Spain. Implementation, Results and Teacher Training. Cambridge Scholars Publishing. Newcastle.

LEE, M. 2002. Second language learning. 19 Oct. 2015. http://www.dls.ym.edu.tw/chudler/ second.html

Lorenzo, F. ET AL. 2005. Orientaciones para la Elaboración del Currículo Integrado de las Lenguas en los Centros Bilingües. Consejería de Educación. Junta de Andalucía.

Lorenzo, F. ET AL. 2010. "CLIL in Andalusia”. CLIL in Spain. Implementation, Results and Teacher Training. Eds D. Lasagabaster and Y. Ruiz de Zarobe. Newcastle. Cambridge Scholars Publishing. 2-12.

Lorenzo, F., Moore, P. \& Casal, S. 2011. “On Complexity in Bilingual Research: The Causes, Effects, and Breadth of Content and Language Integrated Learning: a Reply to Bruton”. Applied Linguistics 32, 4: 450-455.

Maljers, A., Marsh, D., WolfF, D., Genesee, F., Frigols-Martín, M. \& Mehisto, P. 2010. Based on Marsh, D. and Wolff, D. eds. 2007 Diverse Contexts - Converging Goals: CLIL in Europe. Peter Lang: Frankfurt.

MARSH, D. \& LANGÉ, G. 2000. Using Languages to Learn and Learning to Use Languages. Jyväskylá, Finland: UniCOM, University of Jyväskylä on behalf of TIE-CLIL. Part 1: 1-14. 
Marsh, D. ED. 2002. CLIL/EMILE. The European dimension. Actions, trends, and foresight potential. Jyväskylä: University of Jyväskylä.

Marsh, D. ED. 2005. “The CLIL quality matrix”. Central workshop report. 23 Sep. 2014. http://www.ecml.at/mtp2/CLILmatrix/pdf/wsrepD3E2005_6.pdf

MARSH, D. ED. 2006. English as medium of instruction in the new global linguistic order: Global characteristics, local consequences. Finland: UNICOM, Continuing Education Centre, University of Jyväskylä. 10 January 2013. http://www.metsmac.org./2007/ proceedings/2006/Marsh-DMETSMaC-2006.pdf

Martínez Agudo, J. 2012. Teaching and Learning English through Bilingual Education. Newcastle: Cambridge Scholars Publishing.

Mehisto, P., Marsh, D. \& Frigols, M. J. 2008. Uncovering CLIL: Content and Language Integrated Learning in bilingual and multilingual education. Oxford: Macmillan Education.

MeYer, O. 2010 "Towards quality-CLIL: successful planning and teaching strategies". Puls 33: 11-29.

Navés, T., MuÑoz, C. \& PAVESI, M. 2002. “Content and Language Integrated Learning for Second Language Aquisition: SLA for CLIL". TIE-CLIL Professional Development Course. Eds. G. Langé and P. Bertauz. M.I.U.R. Direzione Regionalae Della Lombardia on behalf of TIE-CLIL Project. 53-102.

PÉREZ-CAÑADO, M. L. 2012. “CLIL research in Europe: past, present, future”. International Journal of Bilingual Education and Bilingualism 15, 3: 315-341.

PunTí, I. 2009. The Weather. CLIL unit. Lesson Plan. Nottingham. CEIP Alexandre Galí. Barcelona

SAlaberri Ramiro, S. 2010. "Teacher Training Programmes for CLIL in Andalusia”. CLIL in Spain. Implementation, Results and Teacher Training. Eds. D. Lasagabaster and Y. Ruiz de Zarobe. Newcastle: Cambridge Scholars Publishing. 140-162.

SAlAberri RAmiro, S. \& SÁnchez-PÉRez, M. M. 2012. “CLIL Lesson Planning”. Teaching and Learning English trough Bilingual Education. Ed. J. Martínez Agudo. Newcastle: Cambridge Scholars Publishing. $89-110$.

SuÁREZ, M. L. 2005. "Claves para el éxito del aprendizaje integrado de contenidos y lengua extranjera (AICLE)". Quinta Jornada sobre Aprendizaje Cooperativo. GIAG Group. Bilbao: University of Deusto.

Tejada Molina, G., Pérez Cañado, M. L. \& Luque Agulló, G. 2005. “Current approaches and teaching methods". TEFL in secondary education. Eds. N. McLaren, D. Madrid, and A. Bueno. Granada: Universidad de Granada. 155-209. 